\title{
Auditor Scepticism and Financial Crises: The Nigerian Factor
}

\author{
Umoren Adebimpe Otu, Asogwa Ikenna Elias* \\ Department of Accounting, Faculty of Business Administration, University of Uyo, Akwa-Ibom, Nigeria \\ Email address: \\ bimpeumoren@yahoo.com (A. O. Umeren), asogwaikenna@yahoo.com (I. E. Asogwa) \\ ${ }^{*}$ Corresponding author
}

To cite this article:

Umoren Adebimpe Otu, Asogwa Ikenna Elias. Auditor Scepticism and Financial Crises: The Nigerian Factor. Journal of Finance and Accounting. Vol. 5, No. 4, 2017, pp. 123-130. doi: 10.11648/j.jfa.20170504.11

Received: April 3, 2017; Accepted: April 18, 2017; Published: June 3, 2017

\begin{abstract}
This research is carried out in order to examine auditor scepticism with respect to Nigerian financial crises. The study employed survey research method based on threats to professional scepticism at different structural levels as identified by [14]. The primary data was supplied by 270 respondents who are professional accountants and bankers in Akwa Ibom State, Nigeria. The study utilized principal component factor analysis to identify the component factors in the twenty item questionnaire. Correlation, Kaiser-Meyer-Olkin (KMO) and Bartlett's test of sphericity was performed to assess the factorability of the data. The tests revealed among others; that factors of professional scepticism responsible for financial crises in Nigeria can be first traced to engagement team lapses, followed by individual auditor lapses and then profession/audit firm lapses. The study recommends that effort should be made by audit engagement team leaders in order to set a clear direction of audit work. They should also employ adequate audit planning, supervision and good time management skills.
\end{abstract}

Keywords: Auditor, Scepticism, Financial Crises, Nigeria

\section{Introduction}

The incidence of financial crisis dates back to the early economies in Europe and America. The first crisis to be recorded was the busting of tulip mania in Netherlands in 1637 [19]; [30]. Others includes, the bust in US stock market in 1825 , the popular great depression of 1929 . However, in Nigeria the first known financial crisis since independence occurred in 1973 resulting from the oil crisis [10]. Nigerian economy looked potentially promising after independence but the potentials never materialised. There was a high economic debacle in the country between the year 19831985 that led to a coup that overthrew the military government of the then President Mohamed Buhari by Ibrahim Babangida.

In other to quickly rescue the economy, the then government introduced structural adjustment programme in August 1986 meant to help it secure loans from the International Monetary Fund (IMF) and the World Bank to stem the crises. The crisis continued until the civilian government came to power in 1999. This triggered new hope for the people and but towards the end of that administration from 2007-2008, a more systemic ridden financial crises hit the world from the US. At first, analyst theorized that it will not affect Nigerian economy but the fact was far from what their figures could predict. The crisis was more or less a systemic problem to the rest of the world that had one thing or the order to do with the US. Just as nose suffers when the eyes cry; virtually all the countries of the world that had direct or indirect transactions with the US was affected. Nigeria was not spared from this because of Foreign Direct Investment (FDI) which brought equity finance under pressure and weakened corporate project finance. This affected investment in agriculture, health, education and other infrastructural development in the country. Another area it affected Nigeria was through a downward trend in oil prices.

Presently, Nigerian economy has not recovered from the global financial crisis that hit the world in 2007 cum 2008. As a mixed and middle income economy that is import dependent, Nigerian is bedeviled by high level youth unemployment, hunger, infrastructural decay, civil unrest, militancy, policy summersault and undermined institutional policies. Dearth of strong economic and political will and 
accountability battered the Nigerian economy and has put it at the verge of collapse. Most of these institutions provides public goods and services and constitute avenues through which enormous resources are needlessly siphoned to private pockets without questioning. Technically, responsibility beholds accountability and agency theory says that for providers of funds to believe the account/report given by the trustees/agents, there is need for an independent investigator [5]. According to [6], the 2007/2008 financial crises was caused by breakdown in underwriting standards of subprime loans, poor credit rating and weaknesses in risk management. Many financial institutions in the world crumbled resulting from the global financial crises (because it was systemic in nature) from the west and Nigeria was not exempted from this.

These failures points accusing fingers on the assurance engagement systems from the agencies prior to the crises. An independent examination of the books of the failed institutions were given by auditors. The big question indeed is what went wrong? People wondered whether the independent examiners are no longer independent, could the auditors have lost the trust reposed on them by the principal who appointed them in the first place or are they biased in favour of the agents? Since audit is a search for evidence, it is intended to justify management report (the agent). The concept of audit is justified by information hypothesis, insurance hypothesis and agency theory. Basically, the process and practice of audit involves enormous tasks which resonates to professional scepticism. Auditor scepticism is a highly complicated phenomenon in the practice of accounting. It starts from moral hazard and extend to audit risk i.e the risk that the auditor may express inappropriate audit opinion when financial statements are materially misstated [17]

Auditors are required to exercise professional scepticism by auditing standards throughout the process of audit. This stresses the importance of scepticism and any attempt on the contrary may prompt the auditor(s) insensitivity to high risk factors that may result in material misstatement. Professional scepticism has been defined as being more careful or extra carefulness, it entails going the extra mile in ensuring due diligence by making sure there is a strong persuasive evidence to support argument or management assertions or possessing a questioning mindset [20]; [14]. [8] averred that it is the demonstration of accuracy in risk assessment by auditors without bias. International Standards on Auditing [18] says that professional scepticism is being ready for possibilities of material misstatement resulting from error or fraud and thorough examination of evidence to avoid misinforming the primary users (investors, creditors and lenders). Auditors should have a critical examination of the evidences before them without prejudice. The concern for professional audit through scepticism has led many writers to ask some useful questions like; "How should professional scepticism be enhanced?" [16].

In the light of the above, this research aims to examine auditor scepticism with respect to Nigerian financial crises.
This will be of immense importance to the auditors, bankers, regulators and the general public. This research is in five sections, following section one (the introduction) is section two that covers the reviews of literature relating to auditor scepticism and financial crises. The research methods are examined in section three. Data analysis and interpretation were covered in section four while the concluding part of the research work and recommendations were captured in section five.

\section{The Review of Related Literatures}

This section covers the review of various literatures relating to auditors scepticism and financial crises.

\subsection{Nature of Auditor Scepticism}

As earlier defined, professional scepticism involves a questioning mindset, critical assessment of audit evidence, higher analytical review, alertness to events that provides possible indication of misstatement arising from an intentional or unintentional error or fraud [18]. This means that the auditors are required to possess an 'enquiring mind' [20], the ability of wanting to know more and have a convincing evidence for virtually all actions. [20]; [12] and [22] argued that professional scepticism is exercised at the early stage of the audit planning and performance by questioning the appropriateness and sufficiency of audit evidence, the reliability of management assertions, observation of contradictory evidence, searching conditions that require further audit procedures or analytical processes by comparing relationships and so on. It is only when the auditors are ready and willing to challenge the assertions of the management that fraud can be deterred, reduced or possibly eliminated. However, sufficient, appropriate evidence can be reached to form an opinion on the truthfulness and fairness of the financial statement. The auditor evaluates the assertions of the management given its sufficiency and appropriateness in order to form an independent opinion. [17] summarised the work of an auditor as a search for evidence to support management assertions and be able to express opinion on the true and fair view.

This opinion is limited in scope since audit involves a search for evidence (not only to support) to either support or disprove the assertions of the management. It is a general view that sceptical frame of mind need to be possessed by auditors in other to exercise a professional care and due diligence in performance of their duties [26]; [20]; [12]. However, the extent of scepticism to be exercised by professional auditors remains elusive. This is because, less scepticism will affect the effectiveness of the audit and too much scepticism will give rise to increased cost, delayed audit report and prone to unhealthy relationship between audit partners and the client. It is particularly important to strike a balance to avoid excessiveness and to also work within the time limit and maintain a defined audit process.

Examining the influence of scepticism in the performance of audit and the auditor's attitude towards the performance of 
the audit work is important. However, [12] argued that auditors should not approach audit work with the predisposition that the accounts are misstated rather, the process of gathering evidence, the auditor may find something that could suggest misappropriation, error or fraud and then exercise reasonable scepticism especially if they cast doubt about the authenticity of the evidence or reliability/authority of the individual providing the information.

\subsection{Importance of Auditor Scepticism}

Preliminary investigation into auditor scepticism has thrown more light on its importance. Audit failure has been characterised by over reliance on management assertions, lack of auditor independence, professional indiscipline and so on. (A clear eg is the bankruptcy/failure of RBS, Northern Rock, Lehman Brothers, Bear Stearns, Fannie Mae and Freddie Mac, Enron, WorldCom and so on) including failure to ensure no conflicting explanations, inability to corroborate evidences with third party confirmations. All these suggested that the auditor did not exercise significant scepticism with the exception of Northern Rock where the auditors (PWC) put a covert in the emphasis of matter about its ability to continue as a going concern.

Scepticism however will enhance audit quality. This is needed in order to challenge the management assumptions and maintain appropriate and sufficient audit evidence. The accuracy or otherwise of any assumption can only be determined via scepticism.

Balanced auditor scepticism is very important in audit practice. [3], argued that scepticism is important in raising junior staff auditors because of their closeness with client and involvement in inspection and testing of transactions, hence, have a better chance of identifying suspicious transactions. They also averred that scepticism is important in improving standard of audit work subsequently, this has been included in relevant auditing standard accordingly.

\subsection{Achieving Professional Scepticism in Audit}

In other to achieve scepticism, US panel on audit effectiveness set by SEC in 1998 recommended that;

a. The auditing standard should provide a guidance on how to implement scepticism

b. Professional bodies including audit firms should train auditors on scepticism with emphasis on interviewing and testing skills and promote standard [12].

c. Strong messages from professional bodies complemented by education and training, thorough guidance and procedures, consultation processes, technical support, effective engagement, quality control reviews etc.

d. Insisting on reasons, evidence, justification and proof of or for an action or assertions

e. Consistencies by establishing a link between assertions and their related proofs

f. Constructive alternative explanation and security of data where necessary to establish convincing evidence

\subsection{Threats and Mitigating Factors to Enhance Auditor Scepticism}

A key to understanding, evaluating, and appropriately addressing factors that may either threaten or enhance professional scepticism is to recognize that different factors that come into play at different structural levels of the professional setting [14]. These structural levels are classified into three categories: individual auditor, engagement team, and audit firm/overall audit profession. Table 1 illustrates some of the threats to professional scepticism at different structural levels as well as some of the factors that are in place at each level to foster and encourage the consistent and appropriate application of professional scepticism. The purpose of Table 1 is to highlight the importance of considering threats, mitigating factors, and methods to enhance the application of professional scepticism at the different structural levels.

Table 1. Some threats and factors that enhances auditors skepticism by Structural Level.

\begin{tabular}{|c|c|c|}
\hline Structural level & Threats & Mitigating Factors \\
\hline Individual Auditor & $\begin{array}{l}\text { a. Judgment traps and biases, lack of knowledge and expertise. } \\
\text { b. Deadline pressure, inherited preferences and expectations } \\
\text { c. Auditor character, and personal and cultural attributes }\end{array}$ & $\begin{array}{l}\text { a. Professional licensing and continuing education requirements } \\
\text { b. Supervision, mentoring, review, and inspection of work and } \\
\text { performance evaluations } \\
\text { c. Effective planning, training and audit programs }\end{array}$ \\
\hline Engagement Team & $\begin{array}{l}\text { a. limited resources, ineffective utilization of specialists and } \\
\text { experts } \\
\text { b. Misaligned inspection influence } \\
\text { c. Familiarity linked to audit tenure }\end{array}$ & $\begin{array}{l}\text { d. Planning with involvement of engagement leadership } \\
\text { e. Industry and client experience } \\
\text { f. Fraud brainstorming meetings } \\
\text { g. Required upward consultation }\end{array}$ \\
\hline $\begin{array}{l}\text { Profession/Audit } \\
\text { Firm }\end{array}$ & $\begin{array}{l}\text { a. Conflicts of interest stemming from payor/selector model } \\
\text { b. Insufficient resources devoted to the audit } \\
\text { c. Incentives created by office/regional performance measures } \\
\text { and consequences }\end{array}$ & $\begin{array}{l}\text { a. Tone at the top encouraging high quality auditing and } \\
\text { professional scepticism } \\
\text { b. Independence requirements including prohibition on } \\
\text { providing certain nonaudit services } \\
\text { c. Licensing exams, experience, and continuing education } \\
\text { requirements }\end{array}$ \\
\hline
\end{tabular}

Source: $([20]: 9,10)$

\subsection{Auditor Scepticism and Financial Crises}

Auditors have been largely criticised for not being professionally sceptical. This suggests that questioning more or the approach of presumptive doubt would lead the auditors 
to search for more compelling evidence that could have aborted the countless audit failures including the financial crisis [29].

Academics view scepticism from many perspectives ranging from the angle of trust [28]; [27], accountability pressure and pre-emptive view [15]; [20]. Common knowledge demonstrates that relationship bond develops as the length of time between the auditor and the client increases over time and familiarity is enhanced. As behavioural pattern sets in, mutual trust will tend to replace professional scepticism (which justifies rotation of auditors). However, it gets to a point where the auditor is intrinsically disposed to evidence that corroborates his or her prior beliefs or presumed knowledge [12]. However, excessive doubt may lead to over-auditing, unnecessary bureaucracy, inefficiency, high cost, delayed audit result and so on [16]

The financial crisis was a major incidence in the history that exposed auditor's lack of scepticism and even tried to question the relevance of auditors in the first place. When Lehman Brothers was placed into bankruptcy that set off a huge fall in global stock market in the world [25], people further questioned the role of auditors in the crises; as not long, a systemic failure set in among major commercial and investment banks like the Citigroup, Bank of America, Goldman Sachs, Merill lynch etc and became very reliant on outside financial support [25]; [1]

The pressure for accountability and knowledge of superior's judgement are negative influence on the audit environment [15] and it affects the concept of pre-emptive self-criticism and accountability pressure. [9]; [21]; [4] and [31] are of the view that auditors are accountable to their superiors in making audit judgement under the engagement rule which are in turn made with regard to their preferences thereby inhibiting skepticism. [23]; [4]; [13]

Another angle to scepticism is the impact of corporate culture and behaviour. As stated before, auditors closeness with the client affects his/her professional judgement [28]; [12]. An unfriendly relationship either from an unbearable challenge from the auditor or from a defensive behaviour from the client may be seen as intimidation by the auditor resulting to unhealthy relationship in which there is biasness in responding to the audit enquiries [12]

Professional scepticism requires a continuous questioning to ensure that information obtained is validated by evidence to support the assertions and ensure there is no material misstatement thereby misleading the users. This process requires the auditor to strive hard and ensure sufficient appropriate evidence to validate assertions presumably without bias in line with the requirement of International Auditing and Assurance Standard Board (IAASB). [7], maintains that dearth of professional scepticism is seen as a major contributing factor to SEC enforcement actions, contributing hugely to malpractice claims against auditors over the years [2]

\section{Research Methods}

This study employs a questionnaire survey method on 20 questions based on threats to professional scepticism at different structural levels as identified by [20]. A sample of the survey instrument is provided in Appendix 1. The population of this study are the professional accountants and bankers in Nigeria. The professional accountants and bankers in Akwa Ibom state form the sample of this study. The copies of questionnaires were distributed to 300 respondents based on convenience sampling technique. Respondents were requested to provide responses based upon a five-point Likert scale, ranging from 1 (strongly disagree) to 5 (strongly agree). The study utilizes principal component factor analysis to identify the component factors in the twenty item questionnaire. Questions 1- 6 covers individual auditor factors, questions 7-13 deals with engagement team factors while questions 14 - 20 covers audit firm/profession factors. Correlation, Kaiser-Meyer-Olkin (KMO) and Bartlett's Test of Sphericity were performed to assess the factorability of the data in determining the causal factor for auditor scepticism. The analysis of data were done using IBM SPSS, version 20

\section{Data Presentation, Analysis and Interpretation}

The response rate was $85.66 \%$ based on 257 out of 300 copies of questionnaire returned. Out of 257 respondents, 113 respondents were members of the Institute of Chartered Accountants of Nigeria (ICAN) representing 44\%. 95 respondents were members of Association of National Accountants of Nigeria (ANAN) representing 37\% while 28 respondents were members of Nigerian Institute of Bankers (NIB) representing $11 \%$ and 21 respondents were members of other Professional bodies such as Association of Chartered Certified Accountants (ACCA) representing 8\%.

Table 2. KMO and Bartlett's Test.

\begin{tabular}{lll}
\hline Kaiser-Meyer-Olkin Measure of Sampling Adequacy. & .873 \\
& Approx. Chi-Square & 4167.007 \\
Bartlett's Test of Sphericity & Df & 190 \\
& Sig. & .000 \\
\hline
\end{tabular}

Source: SPSS Output (2017)

Prior to performing the analysis, the correlation matrix was used to check the pattern of relationships. There was no correlation coefficient greater than 0.9 , and no significance above 0.05 . Kaiser-Meyer-Olkin (KMO) was performed to measure the sampling adequacy. The results indicate a value of 0.873 (Table 2), which is above the recommended value of 0.6 [11]. Bartlett's Test of Sphericity showed a significant value at $p=.000$. According to [11], the significant value of Bartlett's Test of Sphericity should be less than 0.05. The results from these tests support the factorability of the correlation matrix, which enables the performance of factor analysis.

Table 3 lists the eigenvalues associated with each factor before extraction, after extraction and after rotation. Before extraction, the result indicates 20 linear components within the data set. The eigenvectors associated with each factor represent the variance explained by that particular linear 
component. This is also displayed in percentages. For example, factor 1 explains $42.039 \%$ of the total variance. It is clear that the first few factors explain relatively large amount of variance. The factors with eigenvalues greater than 1 is extracted and retained for further investigation. They are components 1 (42.039\%), $2(15.52 \%), 3(9.53 \%)$, and 4 (6.29\%), however after extraction the results were $21.15 \%$,
$20.79 \%, 19.315$ and $12.13 \%$ respectively. [20], recommends retaining factors that are above the elbow or breaking in the scree plot because these factors contribute the most to the explanation of the variance in the data set. The scree test (figure 1) suggests only four component factors are relevant and should be retained in the examination of professional scepticism in the present study.

Table 3. Total Variance Explained.

\begin{tabular}{|c|c|c|c|c|c|c|c|c|c|}
\hline \multirow{2}{*}{$\begin{array}{l}\text { Comp } \\
\text { onent }\end{array}$} & \multicolumn{3}{|c|}{ Initial Eigenvalues } & \multicolumn{3}{|c|}{ Extraction Sums of Squared Loadings } & \multicolumn{3}{|c|}{ Rotation Sums of Squared Loadings } \\
\hline & Total & $\begin{array}{l}\% \text { of } \\
\text { Variance }\end{array}$ & $\begin{array}{l}\text { Cumulative } \\
\%\end{array}$ & Total & $\begin{array}{l}\% \text { of } \\
\text { Variance }\end{array}$ & Cumulative \% & Total & $\%$ of Variance & Cumulative \% \\
\hline 1 & 8.408 & 42.039 & 42.039 & 8.408 & 42.039 & 42.039 & 4.231 & 21.153 & 21.153 \\
\hline 2 & 3.105 & 15.524 & 57.563 & 3.105 & 15.524 & 57.563 & 4.158 & 20.792 & 41.945 \\
\hline 3 & 1.906 & 9.529 & 67.092 & 1.906 & 9.529 & 67.092 & 3.861 & 19.306 & 61.251 \\
\hline 4 & 1.259 & 6.293 & 73.385 & 1.259 & 6.293 & 73.385 & 2.427 & 12.133 & 73.385 \\
\hline 5 & .904 & 4.522 & 77.906 & & & & & & \\
\hline 6 & .727 & 3.636 & 81.542 & & & & & & \\
\hline 7 & .548 & 2.740 & 84.282 & & & & & & \\
\hline 8 & .447 & 2.236 & 86.518 & & & & & & \\
\hline 9 & .414 & 2.070 & 88.588 & & & & & & \\
\hline 10 & .358 & 1.791 & 90.379 & & & & & & \\
\hline 11 & .330 & 1.652 & 92.031 & & & & & & \\
\hline 12 & .267 & 1.334 & 93.365 & & & & & & \\
\hline 13 & .237 & 1.187 & 94.552 & & & & & & \\
\hline 14 & .231 & 1.157 & 95.710 & & & & & & \\
\hline 15 & .188 & .940 & 96.650 & & & & & & \\
\hline 16 & .175 & .877 & 97.527 & & & & & & \\
\hline 17 & .155 & .776 & 98.303 & & & & & & \\
\hline 18 & .134 & .668 & 98.971 & & & & & & \\
\hline 19 & .111 & .555 & 99.526 & & & & & & \\
\hline 20 & .095 & .474 & 100.000 & & & & & & \\
\hline
\end{tabular}

Source: SPSS output (2017)

Scree Plot

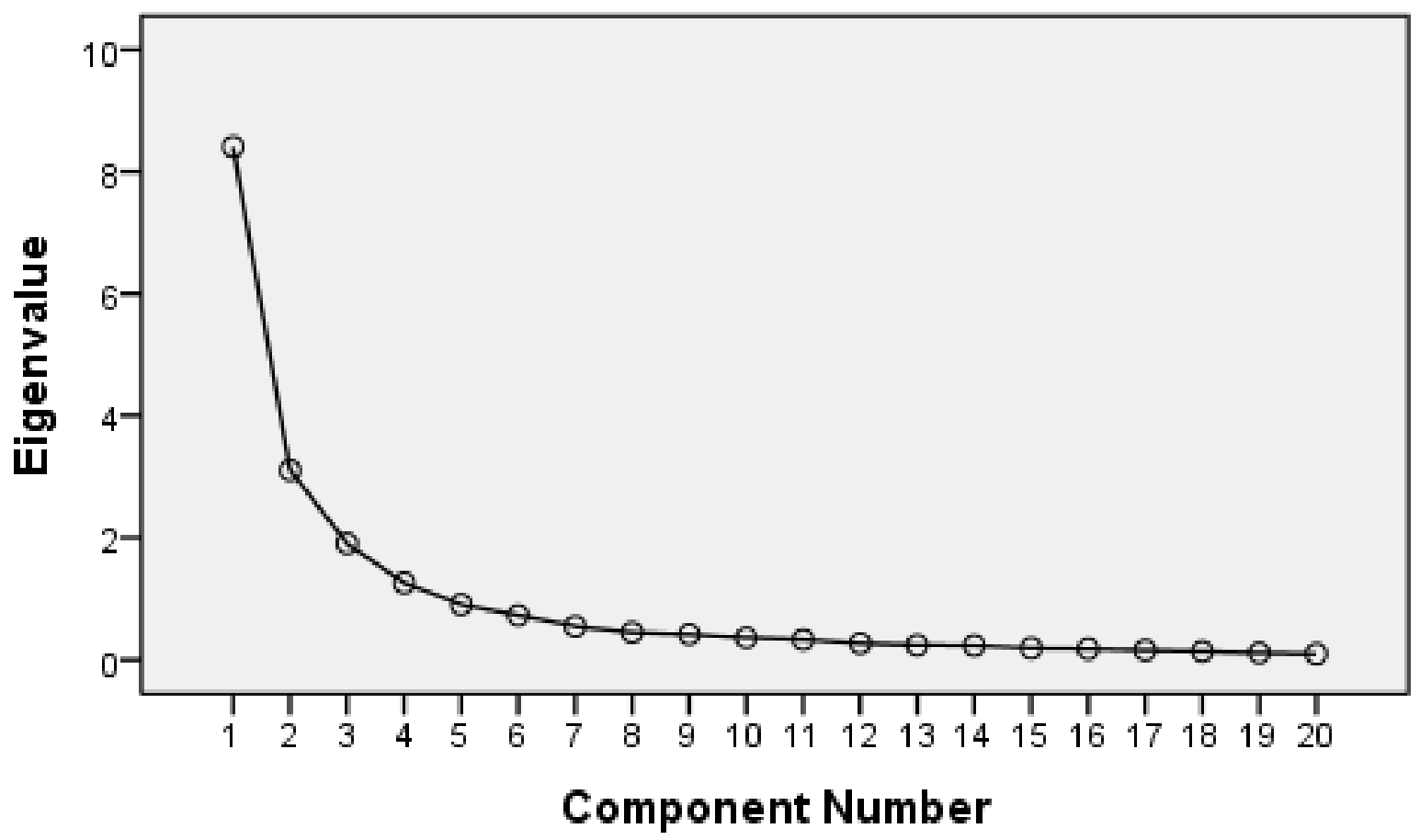

Source: SPSS Output (2017)

Figure 1. Scree Plot. 
The results in table 4 reveal the rotated component matrix which is a matrix of the factor loadings for each variable onto each factor. Four component factors that are extracted from the data explains $73.4 \%$ of the variance. A varimax rotation provides the best defined factor structure. All items had primary loadings over 0.6. The results indicate that eighteen items out of the twenty items of professional scepticism factor scale are extracted and best suited to measure scepticism in the present study. Considering [24], the ideal number of loading on each component should be three or more items. This further eliminates the two factors in component 4 , leaving only sixteen items. Thus, the four items are excluded from the measurement scale due to low factor loading and their failure to meet the pattern matrix. The sixteen items are loaded into three components. Looking at the content of questions that load into the same factor to try to identify the common theme, it is seen that the first component with items $9,10,8,11,12,7$ relates to engagement team level which indicates it is the most crucial factor. The second component with items 3, 4, 2, 5, 1, indicates the second important factor which is individual auditor level, while the third component with items $19,18,5,17,16$, indicates the third important factor which is Profession/ audit firm level.

Table 4. Rotated Component Matrix ${ }^{a}$.

\begin{tabular}{|c|c|c|c|c|c|}
\hline \multirow{2}{*}{ Item } & \multirow{2}{*}{ Statements } & \multicolumn{4}{|c|}{ Component } \\
\hline & & 1 & 2 & 3 & 4 \\
\hline 9 & Inadequate time management & .858 & & & \\
\hline 10 & Ineffective utilization of specialist or expert & .830 & & & \\
\hline 8 & Inadequate audit planning & .797 & & & \\
\hline 11 & Familiarity linked with audit tenure & .753 & & & \\
\hline 12 & Inspection focus that does not fully align with relevant audit risks & .677 & & & \\
\hline 7 & Inadequate audit supervision/mentoring & .650 & & & \\
\hline 6 & Auditor did not follow sound judgement processes & & & & \\
\hline 3 & Auditor familiarity with client staff & & .894 & & \\
\hline 4 & Auditor character, personal and cultural attributes & & .829 & & \\
\hline 2 & Deadline pressure & & .807 & & \\
\hline 5 & Compensation metrics and incentives that do not appropriately encourage professional skepticism & & .766 & & \\
\hline 1 & Lack of adequate knowledge/traning of auditors & & .723 & & \\
\hline 19 & Threat of Losing audit engagement & & & .891 & \\
\hline 18 & Inadequate quality control & & & .845 & \\
\hline 20 & Competition based on Audit fees & & & .830 & \\
\hline 17 & Board audit committees do not understand oversight role & & & .794 & \\
\hline 16 & Nature or volume of nonaudit services & & & .696 & \\
\hline 13 & Practices of engagement leadership that do not adequately emphasis professional skepticism & & & & .808 \\
\hline \multirow[t]{4}{*}{14} & Poor corporate governance structure of the client & & & & .790 \\
\hline & Insufficient resources devoted to the audit & & & & \\
\hline & Extraction Method: Principal Component Analysis. & & & & \\
\hline & & & & & \\
\hline
\end{tabular}

Source: SPSS output (2017)

\section{Conclusion and Recommendations}

The present study finds only 16 of the 20 items suggested by the researchers are relevant in determining the factors of professional scepticism that led to previous financial crises in Nigeria. In addition, the present study finds that the factors of professional scepticism that resulted to financial crises in Nigeria can be first traced to engagement team lapses, followed by individual auditor lapses and then profession/audit firm lapses. This suggests that engagement team leadership is a major factor in the structural level of professional scepticism.

It is recommended therefore that the engagement team leadership should always set a clear direction by ensuring adequate audit planning, supervision and time management.
Professional scepticism can be enhanced through proper high-level internal review and oversight focused specifically on application of scepticism. Individual auditors should have incentives to follow the lead of the supervisor. Furthermore, audit firm leadership should adequately emphasize, incentivize, and support audit quality and the maintenance of a questioning, objective and probing mindset.

\section{Appendix}

Instruction: Please answer the questions in the table below by ticking the spaces provided in the boxes: Strongly Agree (SA), Agree (A), Undecided (U) Disagree (D) and Strongly Disagree (SD).

In your opinion, financial crises in Nigeria were caused by: 
Table A1. Sample Questionnaire.

\begin{tabular}{|c|c|c|c|c|c|c|}
\hline $\mathbf{S} / \mathbf{N}$ & STATEMENTS & $\mathbf{S A}$ & $\mathbf{A}$ & $\mathbf{U}$ & D & SD \\
\hline & Individual auditor factors & & & & & \\
\hline 1 & Lack of adequate knowledge/training of auditors & 5 & 4 & 3 & 2 & 1 \\
\hline 2 & Deadline pressure & 5 & 4 & 3 & 2 & 1 \\
\hline 3 & Auditor familiarity with client staff & 5 & 4 & 3 & 2 & 1 \\
\hline 4 & Auditor character, and personal and cultural attributes & 5 & 4 & 3 & 2 & 1 \\
\hline 5 & Compensation metrics and incentives that do not appropriately encourage professional scepticism & 5 & 4 & 3 & 2 & 1 \\
\hline 6 & $\begin{array}{l}\text { Auditors did not follow sound judgement processes } \\
\text { Engagement team factors }\end{array}$ & 5 & 4 & 3 & 2 & 1 \\
\hline 7 & Inadequate audit supervision/mentoring & 5 & 4 & 3 & 2 & 1 \\
\hline 8 & Inadequate audit planning & 5 & 4 & 3 & 2 & 1 \\
\hline 9 & Inadequate time management & 5 & 4 & 3 & 2 & 1 \\
\hline 10 & Ineffective utilization of specialist or expert & 5 & 4 & 3 & 2 & 1 \\
\hline 11 & Familiarity linked to audit tenure & 5 & 4 & 3 & 2 & 1 \\
\hline 12 & Inspection focus that does not fully align with relevant audit risks & 5 & 4 & 3 & 2 & 1 \\
\hline 13 & $\begin{array}{l}\text { Practices of engagement leadership that do not adequately emphasize professional scepticism } \\
\text { Profession/Audit firm factors }\end{array}$ & 5 & 4 & 3 & 2 & 1 \\
\hline 14 & Poor Corporate governance structure of the Client & 5 & 4 & 3 & 2 & 1 \\
\hline 15 & Insufficient resources devoted to the audit & 5 & 4 & 3 & 2 & 1 \\
\hline 16 & Nature or volume of non-audit services & 5 & 4 & 3 & 2 & 1 \\
\hline 17 & Board Audit committees do not understand oversight role & 5 & 4 & 3 & 2 & 1 \\
\hline 18 & Inadequate quality control & 5 & 4 & 3 & 2 & 1 \\
\hline 19 & Threat of losing audit engagement & 5 & 4 & 3 & 2 & 1 \\
\hline 20 & Competition based on audit fees & 5 & 4 & 3 & 2 & 1 \\
\hline
\end{tabular}

\section{References}

[1] Acharya, V., Cooley. T., Richardson, M. and Walter, I. (2011) Regulating the wall street: The Dodd-Frank Act and the new Architecture of Global Finance, Wiley (332. 10973 REG).

[2] Anderson, S., and J. Wolfe. (2002). A perspective on audit malpractice claims. Journal of Accountancy 194 (3): 59-66.

[3] APB (2012), "Professional skepticism: establishing a common understanding and reaffirming its central role in delivering audit quality", available at: www.frc.org.uk/OurWork/Publications/APB/Briefing-Paper-ProfessionalScepticism.pdf (accessed March, 2015).

[4] Asare, S. K. and Wright, A. M. (2003), "A note on the interdependence between hypothesisgeneration and information search in conducting analytical procedures", Contemporary Accounting Research, 20(2), 235-251.

[5] Asogwa, I. E. (2016) Corporate Governance in Nigerian Banks: a Theoretical Review, International Journal of Management Science and Business Administeration, Vol. 2 (7), 7-15.

[6] Avgouleas, E. (2008) Financial Regulation, Behaviour Finance, and the Financial Credit Crisis in Search of a New Regulatory Model, available at http://www.papers.ssrn.com (accessed on 20/01/2017).

[7] Beasley, M. S., Carcello, J. V. and Hermanson, D. R. (2001). Top 10 audit deficiencies. Journal of Accountancy 191 (4), 63-66.

[8] Cushing, (2003). Economic analysis of skepticism in an audit setting. Working paper, University of Utah. A Model and Literature Review of Professional Skepticism in Auditing.

[9] DeZoort, T., Harrison, P. and Taylor, M. (2006) Accountability and auditors' materialityjudgments: the effects of differential pressure strength on conservatism, variability, and effort,
Accounting, Organizations and Society, 31(4/5), 373-390.

[10] Enetanya, C. C. (2010) An Assessment of Global Financial Crises on Nigerian Banks. Thesis in the Department of Accounting, University of Jos.

[11] Field, A. P. (2005). Discovering statistics using SPSS (2nd edition), London: Sage Financial Reporting Council (2010) Auditor Scepticism: Raising the Bar. London: FRC.

[12] FRC (2010) Revisions to FRC Guidance to on Audit Committees: Non-Audit Services, Available at http://www.frc.org.uk/FRC-Documents/APB/ConsultationDocument-Revisions-to-FRC-Guidance, (accessed February 10th 2017.).

[13] Gibbins, M. and Trotman, K. T. (2002), "Audit review: managers' interpersonal expectations and conduct of the review", Contemporary Accounting Research, 19 (3), 411444.

[14] Glover, S. M. and Prawatt, D. F. (2013), "Enhancing auditor professional skepticism", Global Policy Committee, available at: www.thecaq.org/docs/research/skepticismreport.pdf (accessed 3rd March, 2017).

[15] Gong, F., Kim, S. and Harding, N. (2014). Elevating professional skepticism, an exploratory study into the impact of accountability pressure and knowledge of the superior's preferences, Managerial Auditing Journal, 29 (8), 674-694.

[16] Hurtt, R. K., Brown-Liburd, H. L., Earley, C. E. and Krishnamoorthy, G. (2013), Research on auditor professional skepticism - literature synthesis and opportunities for future research, Auditing: A Journal of Practice and Theory, 32 (S1), 45-97.

[17] Iain, G. and Stuart, M. (2011). The Audit Process, South Wester Centage Learning, UK, 5th Ed.

[18] ISA (UK and Island) 200, Pp 1-35, Available at www.frc.org.uk (accessed on 7th February, 2017). 
[19] Neal, L. and Marc, W. (2003) "Crises in the Global Economy from Tulips to Today: Contagion and Consequences" Globalisation in Historical Perspective, (Chicago: University of Chicago Press) 473-514.

[20] Nelson, M. W. (2009). A model and literature review of professional scepticism in auditing, Auditing: A Journal of Practice and Theory, 28 (2) 1-34.

[21] Nelson, M. W. and Tan, H. T. (2005). Judgment and decision making research in auditing: a task, person, and interpersonal interaction perspective, Auditing: A Journal of Practice and Theory, 24 (1), 41-71.

[22] Nickel, B. (2012) An examination of issues related to professional scepticism in auditing, dissertation, College of Business Administration, University of Central Florida Orlando, Florida.

[23] Peecher, M. E., Piercey, M. D., Rich, J. S. and Tubbs, R. M. (2010), The effects of a supervisor's active intervention in subordinates' judgments, directional goals, and perceived technical knowledge advantage on audit team judgments, Accounting Review, 85 (5), 1763-1786.

[24] Pallant, J. (2007) SPSS Survival Manual. Sydney: Ligare Book Printer.
[25] Pilbeam, K. (2010) Finance and Financial Markets, Palgrave Macmillan, 3rd Ed.

[26] Quadackers, L. M., Groot, T. L. and Wright, A. (2009), Auditors' Skeptical Characteristics and their Relationship to Skeptical Judgments and Decisions", working paper, VU Amsterdam, 2009.

[27] Rennie, M. D., Kopp, L. and Lemon, M. (2010), Exploring Trust and the Auditor-Client Relationship: Factors Influencing the Auditor's Trust of a Client Representative, Auditing: A Journal of Practice and Theory, 29(1) 279-293.

[28] Shaub, M. K. (2015). Trust as threat to independence, Research on Professional Responsibility and Ethics in Accountancy, March, 169-188.

[29] Sikka, P. (2009) Financial crises and silence of th.e auditors: Accounting, Organisation and Society. 34, 68-873.

[30] Swanenburch (2016) Tulip book, Available online at http://www.iisg.nl/collections/crises/crises. (Accessed 18th March, 2017).

[31] Tan, H. T. and Kao, A. (1999) Accountability Effects on Auditors' Performance: The Influence of Knowledge, Problem Solving Ability, and Task Com.plexity, Journal of Accounting Research, Vol. 37 (1), 209-223. 